Bangladesh J. Bot. 49(1): 159-162, 2020 (March)

\title{
EFFECTS OF DIFFERENT PLANT GROWTH REGULATORS ON IN VITRO GROWTH OF ALOE VERA L.
}

\author{
Unaiza Wahab, Muhammad Ashfaq ${ }^{1}$, Muhammad SajJad ${ }^{2}$, Shabnum Shaheen, \\ Riffat Sadique, Muhammad Ali ${ }^{1}$ and Farah Khan* \\ Department of Botany, Lahore College for Women University, Lahore, Pakistan
}

Key words: In vitro growth, MS medium, Pharmaceutical, Micropropagation

\begin{abstract}
An attempt was made to standardize the appropriate concentration of different growth regulators for successful in vitro growth of different explants (leaf, node and internode) of Aloe vera L. Results demonstrated best in vitro growth in leaf explants in MS medium supplemented with BAP (1.0 mg/l) and NAA $(1.0 \mathrm{mg} / \mathrm{l})$ at $\left.26 \pm 2^{\circ} \mathrm{C}\right)$ with $\mathrm{pH} 5.70$ using agar solidified medium and 16 hrs photoperiod.
\end{abstract}

\section{Introduction}

Aloe is a genus of shrubby, monocotyledonous and perennial plant of Liliaceae which consisted of 15 genera and approximately 600 species of Aloe grown around the world and are native to Africa and Spain (Saeed et al. 2004). Various species of Aloe are cultivated as ornamentals due to their sharp pointed spiny leaves and colorful clusters of yellow or red flowers. Commercially two species are grown now a days, which are $A$. barbadensis Mill., also called $A$. vera, and A. arborescence Mill. (Manvitha and Bidya 2014). Aloes were thought to grow only in hot and dry climates, but they actually grow in a variety of climates including desert, grassland, and coastal or even alpine locations (Steenkamp and Stewart 2007). Research on the properties of Aloe has expanded in scope during the last three decades and the production or transformation of value-added compounds, which are medicinally important, still needs to be explored (Badar et al. 2013).

Plant tissue culture offers advantages over traditional methods of propagation, including true to plant types regenerating the plant which has been genetically modified, etc. (Sharifkhani et al. 2011). Meyer and Staden (1991) expressed axillary shoot formation using only IBA, whereas shoot formation was also observed on medium containing 2, 4-D and Kn (Natali et al. 1990, Roy and Sarkar 1991). Richwine et al. 1995 reported the shoots induction using zeatin.

In vitro growth of $A$. vera explants was established using different PGRs on MS medium. Leaf explants showed better results by using BAP $(1.0 \mathrm{mg} / \mathrm{l})$ and NAA $(1.0 \mathrm{mg} / \mathrm{l})$ under $16 \mathrm{hrs}$ photoperiod at $24^{\circ} \mathrm{C}$ and $\mathrm{pH} 5.70$ using $30 \mathrm{~g} / \mathrm{l}$ sucrose on an agar solidified medium.

The purpose of this study was to identify the optimum conditions and proper concentration of different PGRs for in vitro growth of $A$. vera. The above mentioned work may help to improve the plant tissue culture of $A$. vera on a large scale.

\section{Materials and Methods}

Young axillary leaves $(2.0-3.0 \mathrm{~cm})$ of Aloe vera L. were collected from Lahore College for Women University (LCWU) as an explant. The explants were carefully separated and their surface was sterilized by immersing them in $0.12 \% \mathrm{HgCl}_{2}$ for a few minutes. Then this was followed by 3 - 4 times washing with sterile autoclaved distilled water to remove the traces of $\mathrm{HgCl}_{2}$. The sterilized explants were transferred to MS basal medium for the establishment of $A$. vera cultures.

*Author for correspondence: <Drfarah_khann@yahoo.com>. Institute of Agricultural Sciences, University of Punjab, Lahore, Pakistan. ${ }^{2}$ Department of Biosciences, COMSATS University Islamabad (CUI), Pakistan. 
Stock solution for culture medium consisting of different chemicals such as growth regulators, inorganic salts and vitamins was prepared in double distilled water. The stock solutions were then stored in amber colored bottles at $4^{\circ} \mathrm{C}$.

MS (Murashige and Skoog basal agar media (1962), supplemented with different concentrations and combinations of PGRs were used for initiation of callus. The $\mathrm{pH}$ of the medium was adjusted at 5.7 and the medium was gelled with $8.0 \mathrm{mg} / \mathrm{l}(\mathrm{w} / \mathrm{v})$ agar. The sterilization of the medium was performed by autoclaving at $121^{\circ} \mathrm{C}$ for 15 min under 15 psi pressure.

The cultured explants were observed after inoculation and the data were recorded. The results were analyzed by DMRT at $1 \%$ level of significance as described by Steel et al. (1997).

\section{Results and Discussion}

Effects of different explants i.e. leaf internode and node on MS medium supplemented with different concentrations PGRs were investigated. It was observed that leaf explants proved to be the best for in vitro growth of $A$. vera L. (Table 1 and Fig. 1). The leaf explants showed maximum i.e. (96\%) in vitro growth on MS basal medium supplemented with BAP $(1.0 \mathrm{mg} / \mathrm{l})$ and NAA $(1.0$ $\mathrm{mg} / 1$ ) (Fig. 2). Different physical conditions were adjusted i.e. $24 \pm 2{ }^{\circ} \mathrm{C}, 3 \%$ sucrose, $\mathrm{pH} 5.7$ and 16 hrs of photoperiod, respectively. Although comparatively lesser callus (90\%) was formed with BAP $(3.0 \mathrm{mg} / \mathrm{l})$ in MS medium using leaf explants under the same above mentioned physical conditions.

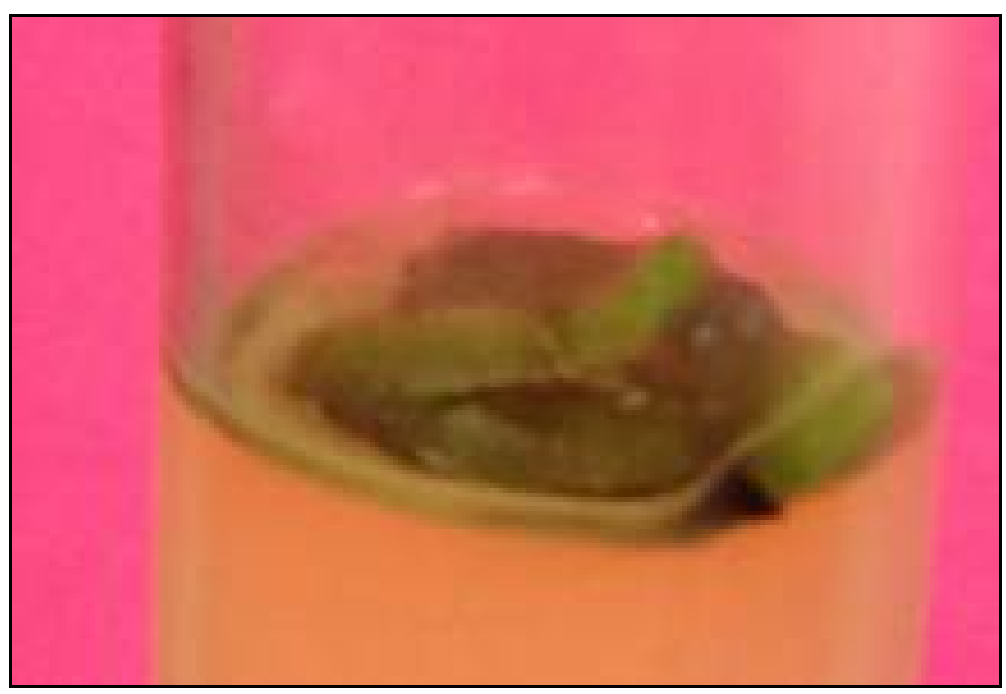

Fig. 1. Regeneration of leaf explant of Aloe vera in MS basal medium supplemented with BAP $(1.0 \mathrm{mg} / \mathrm{l})$ and NAA $(1 \mathrm{mg} / \mathrm{l})$ after 45 days of inoculation.

During the present work, A. vera L. showed maximum (96\%) callus formation using the leaf explants in NAA (1 mg/l) combined with BAP (1 mg/l) on MS. Hashemabadi and Kaviani (2008) investigated on the rapid micro-propagation of $A$. vera and mentioned that best proliferation of shoot per explants (9.67) was obtained on the medium supplemented with $0.5 \mathrm{mg} / \mathrm{l} \mathrm{BAP}+0.5$ $\mathrm{mg} / \mathrm{l} \mathrm{NAA}$. The effect of different concentrations of BAP on different explants was also recorded. Leaf explants gave maximum percentage $(90 \%)$ of callus formation with BAP $(3.0 \mathrm{mg} / \mathrm{l})$. Michael 
and Horiuchi (2006) mentioned that in vitro micropropagated plantlets were regenerated in medium with $2.2 \mathrm{mg} / \mathrm{l}$ BAP. Similar result was reported by Oliveira and Crocomo (2009). In the present work, different concentrations of NAA were used to observe their effect on A. vera explants and maximum growth rate was found to be $78 \%$, using leaf explants with NAA (1.5 $\mathrm{mg} / \mathrm{l})$. Patel and Sail (2012) showed the best callus formation of Aloe vera on medium containing NAA $0.1 \mathrm{mg} / \mathrm{l}$ and Abrie and Staden (2001) also mentioned micropropagation of Aloe on medium containing $1.0 \mathrm{mg} / \mathrm{l} \mathrm{NAA}$.

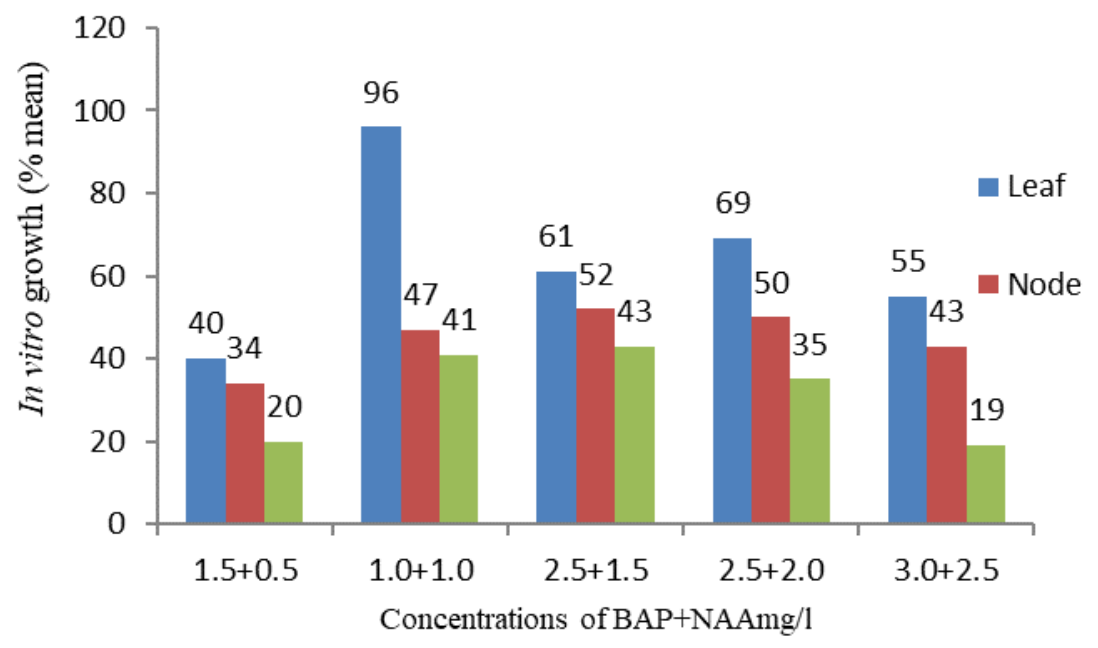

Fig. 2. Effect of different concentrations of BAP and NAA in MS basal medium on in vitro growth of Aloe vera using different explants.

Table 1. Effect of different PGRs in MS medium on in vitro growth of $A$. vera using leaf explants.

\begin{tabular}{llllll}
\hline $\begin{array}{l}\text { Serial } \\
\text { No. }\end{array}$ & $\begin{array}{l}\text { Explant } \\
\text { used }\end{array}$ & $\begin{array}{l}\text { PGRs } \\
(\mathrm{mg} / \mathrm{l})\end{array}$ & $\begin{array}{l}\text { Callusing } \\
(\% \text { mean })\end{array}$ & $\begin{array}{l}\text { Texture of } \\
\text { callus }\end{array}$ & $\begin{array}{l}\text { Color of } \\
\text { callus }\end{array}$ \\
\hline 1. & Leaf & BAP $(3.0)$ & $90 \pm 1.58^{\mathrm{a}}$ & Compact & Yellowish white \\
2. & $"$ & NAA $(1.5)$ & $78 \pm 1.63^{\mathrm{a}}$ & $"$ & White \\
3. & $"$ & $2,4-\mathrm{D}(3.0)$ & $80 \pm 0.34^{\mathrm{a}}$ & $"$ & $"$ \\
4. & $"$ & BAP + NAA & $96 \pm 1.29^{\mathrm{a}}$ & $"$ & Whitish \\
& & $(1.0+1.0)$ & & White \\
\hline
\end{tabular}

The mean with different letter in each column is significantly different according to DMRT (0.05 p value) $\pm=$ Standard error.

The data obtained showing the effect of different PGRs were used for in vitro growth of $A$. vera L. The results suggested that the concentration and combination of the PGRs definitely affected the growth of the plants. 


\section{References}

Abrie AL and Staden JV 2001. Micropropagation of the endangered Aloe polyphylla. Plant Growth Regulation 33(1): 19-23.

Badar Z, Khan S, Ali K, Musharraf SG and Choudhary MI 2013. In vitro and biotransformational studies of Aloe Barbadensis Mill. Pakistani J. Bot. 46(2): 679-685.

Hashemabadi D and Kaviani B 2008. Rapid micropropagation of Aloe vera L. via shoots multiplication. African J. Biotech. 7(12): 1899-1902.

Manvitha K and Bidya B 2014. Aloe vera: A wonder plants its history, cultivation and medicinal uses. J. Pharmacognosy and Phyt. Chem. 2(5): 85-88.

Meyer HJ and Staden JV 1991. Rapid in vitro propagation of Aloe barbadensis Mill. Plant cell, Tissue and Organ Culture 26: 167-171.

Michael, Taunabe J and Horiuchi K 2006. Aloe barbadensis Mill. Ex vitro autotrophic culture. J. Hawaiin Pacific Agri. 13: 55-59.

Murashige T and Skoog F 1962. A revised medium for rapid growth and bioassays with tobacco tissue cultures. Plant Physiol. 15: 473-479.

Natali L, Sanchez IC and Cavallini A 1990. In vitro culture of Aloe barbadensis Mill: Micropropagation from vegetative meristems. Plant Cell Tissue Organ Cul. 20: 71-74.

Oliveira ET and Crocomo OJ 2009. Large scale micropropagation of Aloe vera. Hort. Sci. 44(6): 1675-1678.

Patel D and Sail S 2012. Studies on seed tissue culture and organogenesis of Aloe vera. J. Cell \& Tissue Res. 12(2): 3241.

Richwine AM, Tipton JL and Thompson GA 1995. Establishment of Aloe, Gasteria, and Haworthia shoot cultures from inflorescence explants. Hort. Sci. 30(7): 1443-4.

Roy SC and Sarkar A 1991. In vitro regeneration and micropropagation of Aloe vera L. Scientia Horti. 47(12): 107-113.

Saeed MA, Ahmad I, Yaqub U, Akbar S, Waheed A, Saleem M and Din N 2004. Aloe vera: A plant of vital significance. Quarterly Science Vision 9: 1-2.

Sharifkhani A, Saud HM and Aziz MA 2011. An alternative safer sterilization method for explants of Aloe vera barbadensis Mill. 2nd International Conference on Chemical Engineering and Application 23: 32.

Steel RGD, Torrie HJ and Dickey AD 1997. Principals and Procedures of Statistics. Biometrical approach. $3^{\text {rd }}$ ed. McGraw Hill Books Co. In. New York, USA.

Steenkamp V and Stewart MJ 2007. Medicinal applications and toxicological activities of Aloe products. Pharmaceutical Biol. 45(5): 411-420. 